IV. - FEEDING

\title{
Analytical study of complete mixed feed used in piglet weaning
}

\author{
A. AUMaItre, Jany PEINIAU, Régine CAIMES, Michèle SEGUIN \\ Station de Recherches sur l'Élevage des Porcs, \\ Centre national de Recherches zootechniques, I.N.R.A., \\ $7^{8} 35^{\circ}$ Jouy-en-Josas
}

The technological and chemical characteristics of diets used in piglets weaned at 2 different ages (2I days $=S_{21}$ and 35 days $=S_{35}$ ) were analysed. Eighteen different pellets ( 9 for each weaning age) were obtained from pig production units using these diets.

The diameter of the pellets was small (2.4 and $2.65 \mathrm{~mm}$, respectively on an average) and their length was constant (about $12 \mathrm{~mm}$ ). The durability of the pellets varied very much (from o to 8 p. IOO), and was 1.6 and 3.2 p. I oo respectively on an average. The hardness was higher for the pellets of group $S_{35}$. The two technological criteria were only little correlated and seemed to depend much more on the manufacturing conditions than on the nature of the feed components. The dry matter contents were high and those of hydrochloric acid insoluble ash negligible. The amount of sulphuric acid was low in spite of a high lipid content. The carbohydrate contents were noteworthy and the amounts of fiber ( $\mathrm{ADF}$ and cellulose) low in the two groups. The soluble carbohydrate levels were higher in the feed $S_{21}$ ( $17.6 \mathrm{p}$. 1oo versus $7.6 \mathrm{p}$. I0o) but the variations were large (tabl. 2) : the sucrose content and the lactose supplied by dried milk or whey varied largely. The only suitable method of determination was their extraction with $80{ }^{\circ} \mathrm{G}$. L.-alcohol.

The gross energy content (EB) varied in the same way as the lipid content (fig. 2, tab1. 3). The gross energy values calculated with the equation of Schiemann et al. using the data of the chemical analysis were, on an average, $2.8 \mathrm{p}$. Ioo and $1.7 \mathrm{p}$. IOo higher respectively than those measured with a calorimetric bomb. Some of the feeds showed a slight lysine and sulphur amino acid deficiency as compared to the requirements of piglets weaned at 21 days of age (fig. 3 ). However, all the feeds contained large announts or even an excess of minerals relative to the requirements (tabl. 6 and 7). The amounts of trace elements (manganese, iron) exceeded two to ten times the requirements. The cupper contents were generally too high in feeds $s_{21}$ as compared with recent experimental results on the growth performance in the young.

Weaning diets produced by the animal food industry correspond to the food regulation characteristics and to the experimental estimations of piglet food requirements, varying considerably with the weaning age.

\section{Effect of fish meal in a cereal-soybean post-weaning diet for piglets}

\author{
J.-P. BOUARD (1), J. CASTAING $\left({ }^{2}\right)$, J. FEKETE $\left({ }^{1}\right)$ \\ (1) Institut Technique des Céréales et des Fourrages, \\ 8, avenue du Président-Wilson, 75116 Paris \\ (2) Association Générale des Producteurs de Maïs, \\ $I$, place Samuel-de-Lestapis, 64000 Pau (France)
}

The effect of including $5 \mathrm{p}$. Ioo fish meal in diets based on cereals and soybean meal was investigated during two trials performed on piglets of pure bred Large White sows from " minimal disease "herds. 
- In the first trial involving 86 piglets per treatment, diets containing I 8 and 20 p. Ioo crude protein, with and without fish meal, were used. The weight and mean age of the piglets at the beginnitig and at the end of the trial were the following: $9 \mathrm{~kg}$ at the age of 38 days and $28 \mathrm{~kg}$ at 73 days.

- In the second trial involving I44 piglets per treatment, a diet including $20 \mathrm{p}$. Ioo crude protein with and without fish meal was used. The weight and mean age of the animals at the beginning and at the end of the trial were the following; $9 \mathrm{~kg}$ at 38 days and $24 \mathrm{~kg}$ at 66 days.

The experimental device applied was that of the batch system. For establishing the experimental groups, the animals were chosen according to their weight at weaning and average litter weight at birth. They were weighed individually. After having established the groups (weaning) the animals were fed the starter diet ad libitum in the post-weaning room (flat-decks) where after they received the experimental diets ad libitum till the end of the experiment. The feed intake was recorded per group of piglets (6-7 animals per box).

In the two trials, there was no significant difference between the treatments as for the feed intake levels which amounted to about $\mathrm{I} \mathrm{kg} / \mathrm{day} /$ piglet.

The results of the two trials show that for a given crude protein level, the addition of fish meal to the diet did not significantly affect either the growth or the feed conversion ratio.

The great statistical value of the experitnent involving 642 piglets would most likely have evidenced a 5 p. I 00 difference of growth and feed conversion ratio between the groups, if such a difference had existed.

It may therefore be assumed that when the rearing conditions permit to obtain high performances in the weaned piglets (more than $500 \mathrm{~g} / \mathrm{day}$ ), an increase in the productivity depends most likely on an increase in the supply of crude protein, the advantage of using fish meal, even of good quality, being illusory.

\title{
Processing technology of early weaning feeds for piglets: influence of the physical form (meal or pellets) and the pelleting conditions on the utilization of diets based on barley or maize
}

\author{
P. QUEMERE (1), G. BERTRAND ( $\left.{ }^{(}\right)$, J. MI. PEREZ $\left({ }^{2}\right)$, B. SEVE $\left({ }^{2}\right)$ \\ (1) S.E.R.E.P., Institut Supérieur Agricole, 60026 Beauvais (France) \\ (2) Station de Recherches sur l'Élevage des Porcs, \\ Centre national de recherches zootechniques, I.N.R.A., \\ $7835^{\circ}$ Jouy-en-Josas (France)
}

Three hundred sixty piglets were used to study the influence of the physical form of the feed (maal, pellets obtained by $d r y$ or steam pelleting) on the performance of the piglets after weaning. The possible interactions with the kind of cereal used (barley or maize), the initial weight of the animals ("light " and "heavy " at weaning) and their age (Ist and 2 nd age feeding) were also investigated. Pre starter and starter feeds were isonitrogenous and iso-lysine. The pressing conditions of the pellets, the particle size of the initial meal, the variation in the inletoutlet temperature of the die, the rate per hour of the press as well as the final technological characteristics of the pellets, were described. Use of steam resulted in a harder, more durable pellet and a higher rate per hour of the press than the dry treatment. It was not possible in any case to establish a relationship between hardness measures and feed intake level. However the intake of pellets including barley was lower (- I2 p. IOO) than that of the corresponding meal. The growth rate of the piglets was little affected by the physical form of the feeds based on barley, whereas an $8 \mathrm{p}$. I oo improvement was observed with the dry pelleting of feeds based on maize. The pressing treatment affected in particular the feed efficiency, the effects $(+19$ to $+23 \mathrm{p}$. IOO) being more marked in the young piglets (from the age of 20-25 days, with the Ist age feed) and light ones $(5.1$ to $5.4 \mathrm{~kg})$. On the basis of the whole experimental period, dry pelleting appeared to be more advatitageous ( $+\mathrm{I}_{5}$ and I I p. Ioo, respectively with barley and maize) than steam pressing $(+8$ and +6 p. I0o). Likewise, the cereal which was the least efficient in form of meal (barley) was the best valorized by pelleting. The efficiency of the diets based on maize was $7 \mathrm{p}$. I oo higher than that of the diets based on barley probably because of a higher 